\title{
Respiratory muscle strength of patients with esophagus and stomach neoplasms
}

\author{
Força muscular respiratória de pacientes com \\ neoplasia de esôfago e estômago
}

\author{
Evelyn Aline Boscolo Ruivo, Juliana Rodrigues Correia Mello, Odete Mauad Cavenaghi, \\ Alexandre Lins Werneck, Lucas Lima Ferreira*
}

Faculdade de Medicina de São José do Rio Preto (FAMERP), São José do Rio Preto, SP, Brazil

\begin{abstract}
Introduction: In cancer patients, the reduced food intake causes weight loss and promotes protein-calorie malnutrition. This results in loss of lean body mass, which affects both skeletal muscles and respiratory muscles. Objective: Evaluate and compare the respiratory muscle strength of patients with esophageal and stomach neoplasia during the preoperative period. Methods: This is a cross-sectional study carried out with 24 patients of both genders hospitalized in a teaching hospital. They underwent a physical therapy evaluation composed of anthropometric data and measurement of respiratory muscle strength through manovacuometry. Paired and unpaired t-tests were used to compare the values obtained with the predicted equations. Results: Regarding the disease prevalence, $66.66 \%$ (16) of the individuals had stomach neoplasm and 33.33\% (8) esophageal neoplasm. Of the patients with esophageal neoplasm, 100\% were men with a mean age of $63 \pm 9.16$ years. Of those with stomach neoplasm, $68.75 \%$ were men with a mean age of $69.36 \pm 10.92$ years. Female patients with stomach neoplasm had significantly higher BMI ( $p=0.01)$ than male patients, and they were classified as overweight. Both neoplasms had significantly lower real values $(\mathrm{p} \leq 0.05)$ than predicted values at the maximal expiratory pressure. Conclusion: Patients with esophageal and stomach neoplasms in the preoperative period
\end{abstract}

\footnotetext{
EABR: BS, email: evelyn.ruivo.fisio@gmail.com JRCM: BS, email: jrcfisio@yahoo.com.br OMC: MS, email: bebelmauad2009@hotmail.com ALW: PhD, email: alexandrelinswerneck@gmail.com LLF: MS, email: lucas_lim21@hotmail.com
} 
present reduction in the expiratory muscle strength. There were no statistically significant differences, when we compared the maximum respiratory pressures between the two types of neoplasms investigated.

Keywords: Muscle Strength. Respiratory Muscles. Neoplasms. Esophagus. Stomach.

\section{Resumo}

Introdução: Em pacientes com câncer, a diminuição da ingestão de alimentos ocasiona perda ponderal e promove uma desnutrição protéico-calórica que resulta na perda de massa corporal magra, acometendo tanto músculos esqueléticos, quanto a musculatura respiratória. Objetivo: Avaliar e comparar a força muscular respiratória de pacientes com neoplasia de esôfago e estômago durante o período pré-operatório. Métodos: Estudo transversal com 24 pacientes de ambos os sexos internados em um Hospital-Escola, os quais foram submetidos a uma avaliação fisioterapêutica composta por dados antropométricos e mensuração da força muscular respiratória, por meio da manovacuometria. Comparações dos valores obtidos com as equações preditas foram realizadas pelo teste t pareado e não pareado. Resultados: Quanto à prevalência, 66,66\% (16) dos indivíduos apresentavam neoplasia de estômago e 33,33\% (8), neoplasia de esôfago. Dos pacientes com neoplasia de esôfago, 100\% eram homens com média de $63 \pm 9,16$ anos e, na neoplasia de estômago, 68,75\% eram homens com 69,36 \pm 10,92 anos. Os pacientes com neoplasia de estômago, do sexo feminino, apresentaram IMC significativamente maior $(p=0,01)$ do que os pacientes do sexo masculino, sendo classificadas como sobrepeso. Na pressão expiratória máxima, ambas as neoplasias apresentaram valores reais significativamente menores $(p \leq 0,05)$ aos valores preditos. Conclusão: Pacientes com neoplasia de esôfago e estômago no período pré-operatório apresentam redução na força muscular expiratória. Na comparação das pressões respiratórias máximas, entre os dois tipos de neoplasias investigadas, não houve diferenças estatisticamente significativas.

Palavras-chave: Força Muscular. Músculos Respiratórios. Neoplasia. Esôfago. Estômago.

\section{Introduction}

Esophageal cancer (EC) affects more than 450,000 people worldwide each year. In men, it is the fifth most frequent tumor and it ranks $13^{\text {th }}$ in women. Stomach cancer is the second-leading cause of cancer deaths in both sexes worldwide. It is the second most frequent tumor in men and the third in women (1). These types of neoplasms evolve with proteincalorie malnutrition. This is a fact that changes the strength of the respiratory muscles, especially the expiratory one, resulting in a greater impact on type II fibers, thus, reducing the capacity of relaxation and contraction of these muscles (2).

Studies have shown that EC is common in men (3:1) and in blacks in the $6^{\text {th }}$ and $7^{\text {th }}$ decades of life. Risk factors such as age, alcoholism, and smoking contribute to its etiology, as well as clinical conditions such as megaesophagus and Barrett esophagus. The incidence of gastric CA increases between the ages of 35 to 40 years, and it reaches its apex between the age of 50 to 70 years. It follows different rhythms, and in terms of prevalence, it includes exaggerated consumption of salt, H. pylori infection, precancerous conditions, such as chronic gastritis, intestinal metaplasia, and those undergoing subtotal gastrectomies. Elderly men and underprivileged socioeconomic groups are the most affected ones, regardless of geographic location (3 - 8).

Patients with unintentional weight loss of $5 \%$ or more, at one month, are less likely to survive than those with stable weight are (9). In patients with advanced CA, decreased food intake causes weight loss and promotes protein-calorie malnutrition. The result of this is the loss of lean body mass, functional impairment, and deterioration of physical function caused by catabolism and tissue alteration of skeletal muscles (10 - 13).

Studies have shown that the loss of respiratory muscles is proportional to that of other skeletal muscles, and it may be even greater in some cases. There are changes in lung parenchyma structure, surfactant quality, and inefficient ion transport in the respiratory system. There is a reduction in the thickness, length, and muscular mass of the 
diaphragm. With decrease of muscle strength, cough becomes less effective and leads to a reduction in eliminating secretions. There is an increased risk of atelectasis and pneumonia. It is essential to maintain adequate nutritional support, combined with skeletal muscle training, once muscle weakness is a great predictor of functional degeneration $(14,15)$.

Respiratory muscles are considered the motor driving-force of the pulmonary system, once breathing is a vital function performed by such muscles. Every surgical procedure presents some degree of pulmonary dysfunction, even when the lungs are not directly involved. Therefore, since the beginning of preoperative period, respiratory muscle strength should be recommended (16). Thoracic and/or abdominal surgeries compromise these muscles, which leads to a decrease in strength, hypoxemia, and/ or acute respiratory failure with a high prevalence of postoperative complications (17). Manovacuometry is a low-cost procedure capable of stratifying the risk of changes in respiratory function. It aims through guidelines and evaluation of risk factors the faster patient recovery after the surgery (18).

Currently, esophageal and stomach neoplasms have been prominent in the world statistics. Thus, it is critical to identify the effects of cancer and its treatment over functional aspects, especially regarding respiratory muscle strength, once this directly affects the patients' quality of life. It is expected that the individual with esophageal and stomach neoplasms presents respiratory muscle strength deficit due to poor nutritional status, weight loss, and lean body mass with consequent functional impairment. Therefore, there is a need for further studies on the proposed theme, so that the functional diagnosis can be established early and therapeutic interventions can be effective in the patient rehabilitation. The objective of this study was to evaluate and compare the respiratory muscle strength of patients with esophageal and stomach neoplasms during the preoperative period.

\section{Methods}

This is an observational, cross-sectional, prospective study developed at Hospital de base, in the city of São José de Rio Preto - São Paulo, Brazil.

Inclusion criteria were patients of both sexes, age above 18 years, who were hospitalized and undergoing investigation procedure of esophagus or stomach neoplasms from July to September 2015. The study sample was composed of all individuals hospitalized in this period. Exclusion criteria were individuals with a general state of physical or mental impairment that hindered their collaboration in the functional evaluation; those without a confirmed diagnosis; those with diseases with increased risk of intrathecal pressure, and those already in the postoperative period. The Local Institutional Ethics Committee approved the study under Opinion n\# 1.126.078 and written informed consent was obtained from each patient.

The study participants have undergone a physiotherapeutic evaluation, and the information collected was attached to a file prepared by the researchers, which contained data such as age, gender, body mass index (BMI), and evaluation of respiratory muscle strength through manovacuometry.

Regarding functional evaluation (BMI), the patient's body weight and height were taken into account for low weight, adequate weight, pre-obesity, and obesity levels (class I, II, and III) (19).

The study participants' weight loss of pre and postdiagnosis of esophagus and stomach neoplasms was considered in the BMI item, but the anthropometric variables were not considered outcome variables for this study. This data was highlighted because the literature associates the loss of body mass resulting from cancer with functional impairments due to weakness in the skeletal and respiratory musculature. However, we did not use statistical analysis to correlate weight loss with reduction of inspiratory and expiratory muscle strengths among the evaluated patients.

Respiratory evaluation was obtained using an analog manovacuometer $\left(\mathrm{Wika}^{\circledR}\right)$. Patient was positioned seated on bed with pending lower limbs, keeping his/her shoulders relaxed, as well as accessory muscles of the breath. In order to obtain maximal inspiratory pressure (MIP) measurement, the patientwas askedto perform maximum inspiratory and expiratory efforts to reach the residual volume, and afterwards the patient should perform a maximum inspiratory effort. At maximal expiratory pressure (MEP), the evaluation occurred through maximal inspiration up to the total lung capacity, followed by a maximum expiratory effort. For each pressure, three repetitions were performed. An interval of one-minute recovery was observed after each repetition to learn the technique. We considered the highest value obtained (20 - 22). 
In order to calculate maximum respiratory pressures according to age and sex, for men and women aged 20 to 80 years, we used regression equations based on the values predicted by the equations of Neder et al. (23).

\begin{tabular}{cc}
\hline Men & Women \\
\hline MIPRV $\left(\mathrm{cmH}_{2} \mathrm{O}\right)=$ & MIPRV $\left(\mathrm{cmH}_{2} \mathrm{O}\right)$ \\
$155.3-0.80 \times$ age & $=110.4-0.49 \times$ age \\
\hline MEPTLC $\left(\mathrm{cmH}_{2} \mathrm{O}\right)=$ & MEPTLC $\left(\mathrm{cmH}_{2} 0\right)=$ \\
$165.3-0.81 \times$ age & $115.6-0.61 \times$ age \\
\hline
\end{tabular}

In a young adult, MIP values range from -90 to -120 $\mathrm{cm} \mathrm{H}_{2} \mathrm{O}$ and MEP of +100 to $+150 \mathrm{~cm} \mathrm{H}_{2} \mathrm{O}$. MIP values between - 70 to $-45 \mathrm{~cm} \mathrm{H}_{2} \mathrm{O}$ indicates weakness; values ranging from -40 to $-25 \mathrm{~cm} \mathrm{H}_{2} \mathrm{O}$ indicates fatigue; values below $-20 \mathrm{~cm} \mathrm{H}_{2} \mathrm{O}$ demonstrates respiratory muscle failure, and MIP less than $-50 \mathrm{~cm} \mathrm{H}_{2} \mathrm{O}$ suggests inability to breathe large volumes and ineffective cough (20).

We did not include a control group because the comparison of the respiratory pressures was made through formulas predicted for each gender and age, which were available within the literature. These were taken as a basis for the calculation of respiratory muscle strength in the patients on this study. This made it possible to compare the normality value, which resembles to a control group for a given gender and age of a healthy individual in relation to the same gender and age. However, in this case, the patient had esophageal and stomach newoplasia.

We used descriptive statistics and data are expressed as mean \pm SD, absolute numbers and percentages. We used inferential statistics. Normality was tested with the Shapiro-Wilk tests. Anthropometric and functional variables were compared using paired and unpaired tests.
Statistical analyzes were performed using SPSS for Windows ${ }^{\circledR}$, version 17.0 (SPSS, Chicago, IL, USA). P $\leq$ 0.05 was consideredstatistically significant.

\section{Results}

The study sample consisted of 24 individuals. Regarding esophagus and stomach neoplasms, the prevalent gender was males $8(100 \%)$ and 11 (68.75\%), respectively. Table 1 presents sociodemographic data, including age; body mass, height, and BMI. In relation to patients' age group with stomach neoplasm, the mean age was 69.36 \pm 10.92 years for men (minimum age of 44 and a maximum of 90 years). Women had a mean age of $59.4 \pm 14.8$ (minimum age of 43 and a maximum of 81 years). In esophagus neoplasm, mean age among males was $63 \pm 9.16$ years (minimum age of 53 and maximum of 79 years).

Stomach neoplasia female patients had significantly higher BMI $(p=0.01)$ than male patients, and they were classified as overweight. There were no females in the esophagus neoplasm patients group, which made it impossible to compare genders (Table 1).

In respiratory muscle strength, data showed that there were no statistically significant differences for Maximum Inspiratory Pressure. According to Table 2, as for Maximum Expiratory Pressure, it was observed that both male and female patients with stomach and esophagus neoplasms had significantly lower values ( $\mathrm{p} \leq 0.05)$ than the predicted values.

According to Table 3, when comparing maximal respiratory pressures between the two types of neoplasms investigated, it was verified that there were no statistically significant differences for MIP and MEP.

Table 1 - Patients anthropometric and clinical characteristics

\begin{tabular}{|c|c|c|c|c|c|}
\hline \multirow{2}{*}{ Variable } & \multicolumn{2}{|c|}{ Stomach Neoplasm } & \multirow[b]{2}{*}{$\mathrm{p}$-value } & \multicolumn{2}{|c|}{ Esophagus Neoplasm } \\
\hline & Male & Female & & Male & Female \\
\hline n (\%) & $n=11(68.75 \%)$ & $n=5(31.25 \%)$ & - & $n=8(100 \%)$ & - \\
\hline Age (years) & $69.36 \pm 10.92$ & $59.4 \pm 14.8$ & 0.15 & $63 \pm 9.16$ & - \\
\hline Body Mass (kg) & $61.45 \pm 9.13$ & $72.30 \pm 21.09$ & 0.16 & $62.2 \pm 14.8$ & - \\
\hline Height (meters) & $1.68 \pm 0.10$ & $1.60 \pm 0.11$ & 0.16 & $1.71 \pm 0.06$ & - \\
\hline \multicolumn{6}{|l|}{ Body Mass (kg/m²) } \\
\hline Pre-diagnosis & $23.88 \pm 4.99$ & $29.33 \pm 5.48$ & $0.06^{*}$ & $25.03 \pm 4.28$ & - \\
\hline \multirow[t]{2}{*}{ Post-diagnosis } & $21.68 \pm 2.62$ & $27.91 \pm 5.97$ & $0.01^{*}$ & $21.23 \pm 4.61$ & - \\
\hline & $p=0.27^{\dagger}$ & $p=0.76^{+}$ & & $p=0.03^{\dagger}$ & \\
\hline
\end{tabular}


Table 1 - Patients anthropometric and clinical characteristics

(Conclusion)

\begin{tabular}{|c|c|c|c|c|c|}
\hline \multirow{2}{*}{ Variable } & \multicolumn{2}{|c|}{ Stomach Neoplasm } & \multicolumn{3}{|c|}{ Esophagus Neoplasm } \\
\hline & Male & Female & $\mathrm{p}$-value & Male & Female \\
\hline \multicolumn{6}{|l|}{ Diagnosis time } \\
\hline Between 1 to 5 months & 09 & 04 & & 07 & \\
\hline 6 months or over & 02 & 01 & & 01 & \\
\hline
\end{tabular}

Note: $\mathrm{n}=$ number of patients; $\mathrm{Kg}=$ kilogram; $\mathrm{m}=$ meters; $\mathrm{Kg} / \mathrm{m}^{2}=$ kilogram per square meter; *Unpaired $\mathrm{t}$ test; $\dagger$ Paired $\mathrm{t}$ test.

Source: Data provided by the researchers.

Table 2 - Comparison of maximal respiratory pressures found and predicted of patients with stomach and esophagus neoplasms according to gender

\begin{tabular}{|c|c|c|c|c|c|c|}
\hline \multirow{2}{*}{ Gender } & \multicolumn{6}{|c|}{ Stomach Neoplasm } \\
\hline & Obtained MIP & Predicted MIP & $p$-value* & ObtainedMEP & Predicted MEP & p-value* \\
\hline Male & $94.54 \pm 81.53$ & $104.85 \pm 6.00$ & 0.67 & $65.45 \pm 45.02$ & $188.85 \pm 19.72$ & $<0.0001$ \\
\hline \multirow[t]{2}{*}{ Female } & $80 \pm 73.48$ & $73.02 \pm 9.41$ & 0.82 & $50 \pm 34.64$ & $135.87 \pm 13.00$ & 0.007 \\
\hline & \multicolumn{6}{|c|}{ Esophagus Neoplasm } \\
\hline $\begin{array}{l}\text { Male } \\
\text { Female }\end{array}$ & $\begin{array}{c}105 \pm 58.06 \\
-\end{array}$ & $\begin{array}{c}108.35 \pm 5.04 \\
-\end{array}$ & 0.87 & $\begin{array}{c}76.25 \pm 29.24 \\
-\end{array}$ & $\begin{array}{c}204.19 \pm 19.52 \\
-\end{array}$ & $<0.0001$ \\
\hline
\end{tabular}

Note: MIP = maximum inspiratory pressure; MEP = maximum expiratory pressure; ${ }^{*}$ paired $t$ test.

Source: Data provided by the researchers.

Table 3 - Comparison of maximum respiratory pressures found between male patients with stomach and esophageal neoplasms

\begin{tabular}{lccccccc}
\hline \multirow{2}{*}{ Gender } & \multicolumn{3}{c}{ MIP } & & \multicolumn{2}{c}{ MEP } \\
\cline { 2 - 8 } & $\begin{array}{c}\text { Stomach } \\
\text { Neoplasm }\end{array}$ & $\begin{array}{c}\text { Esophagus } \\
\text { Neoplasm }\end{array}$ & p-value* & $\begin{array}{c}\text { Stomach } \\
\text { Neoplasm }\end{array}$ & $\begin{array}{c}\text { Esophagus } \\
\text { Neoplasm }\end{array}$ & p-value* \\
\hline Male & $94.54 \pm 81.53$ & $105 \pm 58.06$ & 0.76 & $65.45 \pm 45.02$ & $76.25 \pm 29.24$ & 0.56 \\
\hline
\end{tabular}

Note: *Unpaired t test. Source: Data provided by the researchers.

\section{Discussion}

In this study, the evaluation of maximal respiratory pressures identified that MEP in both neoplasms presented values significantly lower than the predicted ones, which demonstrates a strength deficit in the expiratory muscles. There were no statistically significant differences in the comparison of these pressures between the types of neoplasms. Systematic searches on databases did not identify similar studies investigating patients' respiratory muscle strength related to esophagus and stomach neoplasms in the preoperative period. This fact prevents any possible comparisons and limits the inferences about the results obtained.
A recent study has evaluated respiratory and peripheral muscle strength in cancer patients (CA) and in patients with benign diseases. The authors divided the 55 patients into two groups: patients with CA and patients with benign disease. They have observed that the CA group presented a decrease in pulmonary function and in both expiratory and peripheral muscle strength when compared to the benign disease group (24). These data corroborate the findings of the present study, in which patients with stomach and esophageal neoplasms presented reduction of the expiratory muscle strength. However, the study in question did not characterize in the analyzed population the CA type. According to the literature, this strength deficit of the expiratory 
muscles in CA patients could be explained by oncologic cachexia and sarcopenia that result in loss of strength and mainly reduction of respiratory capacity in these patients (25).

Other authors evaluated respiratory muscle strength in 59 patients with lung cancer with a mean age of $58.5 \pm 9.46$ years in the preoperative period. Regarding MEP, there was a significant difference between obtained and predicted values. However, there was no relevant difference for MIP (26). Once again, we verified that literature data, even in the case of another type of neoplasm, corroborate the results of the current study, in which, for stomach and esophagus neoplasms the values obtained for MEP were significantly lower than the predicted values. Notwithstanding, comparisons between the studies are not plausible because neoplasm sites are different. However, the literature reports that esophagus neoplasm may be a manifestation of lung neoplasm.

Respiratory muscle strength was also evaluated in 20 patients undergoing breast cancer surgery. In the preoperative period, it was found reduced respiratory muscle strength in relation to the predicted values for each patient. MIP and MEP were $43.14 \%$ and $40.09 \%$ of predicted, respectively. Comparing preoperative respiratory muscle strength and postoperative results, we found that MIP and MEP ( $p<0.001)$ presented reduction in the postoperative period (27). These findings are credited by the authors due to the effects of the surgical procedure, such as anesthesia, pain-dependent hypoventilation, ineffective cough, and central nervous system depression imposed by anesthetic drugs.

According to the literature, the reduction of MEP may be associated with changes in respiratory mechanics, which alter the ventilatory pattern. Overweight or obesity may cause a decrease of alveolar ventilation and explain the reduced value of maximal expiratory pressures. On the other hand, the reduction of MIP is associated with diaphragmatic dysfunction, which reduces ventilation in the lower lung lobes and has an impact on tidal volume and vital capacity (17).

In the sample analyzed in the present study, there was a reduction of body mass in both neoplasms. However, this reduction was only significant for the esophagus neoplasm group of patients. According to the literature, malnutrition caused by neoplasms affecting the gastrointestinal tract alters the strength of the expiratory muscles. This malnutrition causes a greater impact on type II muscle fibers, reducing the capacity of relaxation and contraction of these muscles. As inspiratory muscles, especially the diaphragm, have a greater portion of type I muscle fibers, which are relatively spared during the weight loss process, it is possible to justify MIP maintenance and MEP decrease in these individuals $(2,14)$.

Current evidence suggests that cancer patients with normal or elevated body mass also have a high prevalence of sarcopenia, indicating that this characteristic is not necessarily related to malnutrition (28). This can be observed among the women of the present study who were classified as overweight. It can also be observed in those individuals who did not show weight loss because during evaluation, they have shown a reduction from the maximum respiratory pressures.

Another study reports that the decrease in MEP also occurs due to the lack of training of the expiratory musculature, because during quiet breath, the expiration happens passively, but it becomes active during physical activity and voluntary hyperventilation. Therefore, changes in the MEP can trigger dysfunction of the tonsil capacity with the buildup of secretions and consequent pneumonia (16).

Conversely, other authors concluded that patients with CA show a decrease of 50\% in MIP, generated during the manovacuometry. This inability to generate normal pressures may be due to the effects of CA on the central nervous system, inspiratory muscle atrophy, or isotonic contractile dysfunction of the diaphragm $(29,30)$. These findings differ from the results of the present study, which did not identify loss of inspiratory muscle strength. An experimental study demonstrated a 14\% decrease in the percentage of type I muscle fibers and a 13\% increase in type II muscle fibers of the diaphragm. The animals evaluated showed a significant decrease in the strength of this muscle. The cause was related to a sarcomeric dysfunction with degradation of myosin heavy chain with a decrease of $27 \%$ without decrease in actin, troponin, and tropomyosin $(31,32)$.

The scarcity of articles evaluating respiratory muscle strength of patients with esophagus and stomach neoplasms made it impossible to compare and discuss the results obtained in the present study with the findings of the literature. Nevertheless, according to the bibliographic survey, the expiratory musculature seems to be more commonly 
affectedcompared to the inspiratory muscle, even in different situations than the neoplasm itself.

The present study has as limitations, the small sample size resulting from the prospective inclusion of the patients and the absence of classification of CA stage. Besides, the theme is not much addressed. Such limitations were due to the reduced period for inclusion of patients, and it can be inferred that longer periods could make the sample more homogeneous. In view of this reality, the importance of developing more studies that evaluate the respiratory muscle strength of patients with esophageal and stomach neoplasms in the daily clinic is essential. The results of this study demonstrated that these patients present a decrease in MEP. According to the course of the disease, a significant weight loss is expected over a short period, with loss of lean body mass leading to degeneration of skeletal and respiratory muscle function.

\section{Conclusion}

Patients with esophageal and stomach neoplasms evaluated in the preoperative period had an expiratory muscle strength reduction when the value obtained was compared to the predicted one. No differences in respiratory muscle strength were observed comparing esophageal and stomach neoplasms.

\section{References}

1. Estimativa 2014: Incidência de câncer no Brasil. [cited 2015 Jun 10]. Available from: https://tinyurl.com/ y95ugga9.

2. Lopes J, Russell DM, Whitwell J, Jeejeebhoy KN. Skeletal muscle function in malnutrition. Am J Clin Nutr. 1982;36(4):602-10.

3. Pinheiro VER, Marcondes CA, Sousa MP. Análise epidemiológica das neoplasias de esôfago atendidas no Hospital Universitário Walter Cantídio da Universidade Federal do Ceará (UFC) - período de 2001 a 2010. GED Gastroenterol Endosc Dig. 2012;31(1):1-6.

4. Jozala E, Infante S, Marchini JS, Okano N. Alcoolismo, tabagismo e carcinoma epidermoide de terço médio de esôfago: estudo tipo caso-controle. Rev Saúde Pública. 1983;17(3):221-5.
5. Silva DR, Curado MP, Oliveira JC. High incidence of esophageal cancer in central-western Brazil: a migrant effect? Eur J Cancer Prev. 2013;22(3):235-43.

6. Warken AP, Bosco SMD. Terapia nutricional enteral em pacientes com câncer de esôfago: Relato de caso. Rev Destaq Acad. 2014;6(3):59-63.

7. Monteiro NML, Araújo DF, Soares EB, Vieira JPFB, Santos MRM, Oliveira Junior PPL, et al. Câncer de esôfago: Perfil das manifestações clínicas, histologia, localização e comportamento metastático em pacientes submetidos a tratamento oncológico em um centro de referência em Minas Gerais. Rev Bras Cancerol. 2009;55(1):27-32.

8. Campos ECR, Pinheiro EBA, Baldissera RL, Kamel DJ, Santos FMR, Guedes A, et al. Análise de fatores prognósticos no tratamento cirúrgico do câncer gástrico. Rev Med Res. 2012;14(2):1-9.

9. Dias VM, Coelho SC, Ferreira FMB, Vieira GBS, Cláudio MM, Silva PDG. 0 grau de interferência dos sintomas gastrintestinais no estado nutricional do paciente com câncer em tratamento quimioterápico. Rev Bras Nutr Clin. 2006;21(2):104-10.

10. Pereira EEB, Santos NB, Sarges ESNF. Avaliação da capacidade funcional do paciente oncogeriátrico hospitalizado. Rev Pan-Amaz Saude. 2014;5(4):37-44.

11. Poziomyck AK, Weston AC, Lameu EB, Cassol OS, Coelho LJ, Moreira LF. Preoperative nutritional assessment and prognosis in patients with foregut tumors. Nutr Cancer. 2012;64(8):1174-81.

12. Aquino JLB, Said MM, Pereira DAR, Cecchino GN, Merhi VAL. Avaliação das complicações da esofagectomia de resgate na terapêutica cirúrgica do câncer de esôfago avançado. ABCD, Arq. Bras. Cir. Dig. 2013; 26(3):1-7.

13. Loh KW, Vriens MR, Gerritsen A, Rinkes IHB, Hillegersberg RV, Schippers C, et al. Unintentional weight loss as indicator of malnutrition in surgical cancer patients. Neth J Med. 2012;70(8):365-9.

14. Lunardi AC, Miranda CS, Silva KM, Cecconello I, Carvalho CR. Weakness of expiratory muscles and pulmonary complications in malnourished patients undergoing upper abdominal surgery. Respirology. 2012;17(1):108-13. 
15. Lan CC, Yang MC, Lee CH, Huang YC, Huang CY, Huang KL. Pulmonary rehabilitation improves exercise capacity and quality of life in underweight patients with chronic obstructive pulmonary disease. Respirology. 2011;16(2):276-83.

16. Santos FTI, Biazotto KS, Santos VM, Nasrala MLS. Avaliação da força muscular respiratória de pacientes submetidos à cirurgia abdominal alta e cirurgia torácica. Coorte Rev Cient Hosp St Rosa. 2010;1(1):19-29.

17. Santos CA, Rabelo BAS, Borges DL, Silva MGB, Silva TM. Avaliação da força muscular respiratória de pacientes submetidos à colecistectomia videolaparoscópica. ASSOBRAFIR Cienc. 2016;7(1):35-42.

18. Medeiros AIC, Oliveira AS, Costa SKA, Barbosa LM, Oliveira GWS. Avaliação da função pulmonar, força muscular respiratória e qualidade de vida no préoperatório de cirurgia cardíaca. Rev Fisioter S Fun. 2016;5(2):14-22.

19. Nozaki VT, Rossi NM. Imagem Corporal: Cirurgia Bariátrica. Saude Pesqui. 2010;3(2):185-91.

20. Souza RB. Pressões respiratórias estáticas máximas. J Pneumol. 2002;28(Supl 3):S156-65.

21. Meneghetti CHZ, Figueiredo VE, Guedes CAV, Batistela ACT. Avaliação da força muscular respiratória em indivíduos acometidos por acidente vascular cerebral. Rev Neurocienc. 2011;19(1):56-60.

22. Pontes JF, Ferreira GMH, Fregonezi G, Sena-Evangelista KCM, Dourado Jr ME. Força muscular respiratória e perfil postural e nutricional em crianças com doenças neuromusculares. Fisioter. Mov. 2012;25(2):253-61.

23. Neder JA, Andreoni S, Lerario MC, Nery LE. Reference values for lung function tests. II. Maximal respiratory pressures and voluntary ventilation. Braz J Med Biol Res. 1999;32(6):719-27.

24. Avino BCT. Comparação do impacto da hospitalização nas forças musculares respiratória e periférica e na funcionalidade em portadores de câncer e em portadores de doenças benignas não restritos ao leito. In: Conic-Semesp; $14^{\circ}$ Congresso Nacional de Iniciação Científica. São Paulo: Universidade Cidade de São Paulo; 2014. 12 p.
25. Pastore CA, Oehlschlaeger MHK, Gonzalez MC. Impacto do estado nutricional e da força muscular sobre o estado de saúde geral e qualidade de vida em pacientes com câncer de trato gastrintestinal e de pulmão. Rev Bras Cancerol. 2013;59(1):43-9.

26. Baltieri L, Passos AIM, Galhardo FDM, Roceto LS, Toro IFC. Avaliação pré-operatória da força muscular respiratória, da função pulmonar e da capacidade funcional de pacientes submetidos à ressecção pulmonar. ABCS Health Sci. 2015;40(1):22-7.

27. Abreu APM, Endres D, Costa AB, Zanini SCC, Martini RR, Leguisamo CP. Função pulmonar e força muscular respiratória em pacientes submetidas à cirurgia oncológica de mama. Rev Bras Cancerol. 2014;60(2):151-7.

28. Prado CM, Lieffers JR, Bowthorpe L, Baracos VE, Mourtzakis M, McCargar LJ. Sarcopenia and physical fuction in overweight patients with advanced cancer. Can J Diet Pract Res. 2013;74(2):69-74.

29. Feathers LS, Wilcock A, Manderson C, Weller $\mathrm{R}$, Tattersfield AE. Measuring inspiratory muscle weakness in patients with cancer and breathlessness. J Pain Symptom Manage. 2003;25(4):305-6.

30. Murphy KT, Chee A, Gleeson BG, Naim T, Swiderski K, Koopman R, et al. Antibody-directed myostatin inhibition enhances muscle mass and function in tumor-bearing mice. Am J Physiol Regul Integr Comp Physiol. 2011;301(3):R716-26.

31. Roberts BM, Ahn B, Smuder AJ, Al-Rajhi M, Gill LC, Beharry AW, et al. Diaphragm and ventilatory dysfunction during cancer cachexia. FASEB J. 2013;27(7):2600-10.

32. Eley HL, Skipworth RJ, Deans DA, Fearon KC, Tisdale MJ. Increased expression of phosphorylated forms of RNA-dependent protein kinase and eukaryotic initiation factor $2 \alpha$ may signal skeletal muscle atrophy in weight-losing cancer patients. Br J Cancer. 2008;98(2):443-9.
Received on $05 / 12 / 2016$

Recebido em 12/05/2016

Approved on 06/21/2017

Aprovado em 21/06/2017 